\title{
PREPAREDNESS OF EARTHQUAKE DISASTER FOR COMMUNITIES KOTO TANGAN SUB-DISTRICT - PADANG CITY (CASE STUDY OF ELEMENTARY SCHOOL 31 PASIR KANDANG)
}

\author{
*Arman $\mathrm{A}^{12}$, Ganefri ${ }^{2}{ }^{3}$, Nurhasan Syah ${ }^{24}$ \\ ${ }^{* 1}$ Department of Civil Engineering, Institute of Padang Technology (ITP) - Indonesia \\ ${ }^{2}$ Doctoral Program of Environmental Science, Universitas Negeri Padang - Indonesia \\ ${ }^{3}$ Department of Electrical Engineering, Universitas Negeri Padang - Indonesia \\ ${ }^{4}$ Department of Civil Engineering, Universitas Negeri Padang - Indonesia \\ Email: arman.agung@itp.ac.id
}

*Corresponding Author, Received: March 8, 2021. Revised: March 21, 2021. Accepted: May 20, 2021

\begin{abstract}
In the last five years, the west coast of Sumatra island has experienced several earthquakes with strong intensity. The Pariaman earthquake on September 30, 2009, as reported by USGS, was located on the west coast of Pariaman with a magnitude of 7.9 SR and MMI VII-VIII standard, with a depth of $80 \mathrm{~km}$. has caused victims to humans and property which is quite large. The socialization carried out is in the form of presentations in the classroom. The material presented includes the definition of a disaster, types of disasters (natural, non-natural, and social disasters), disaster management (before a disaster, when a disaster occurs, after a disaster).
\end{abstract}

Keywords: Communication, Earthquake, Mitigation, Risk, Padang

\section{INTRODUCTION}

As we all know, in general, an earthquake with a large enough scale will cause structural and nonstructural damage to buildings made of reinforced concrete construction [1-6]. The form and level of damage that occurred ranged from mild to severe. The earthquake rocked the city of Padang on September 30, 2009, and caused losses in the form of loss of life, government facilities, the economy, housing, and living activities [7-9].

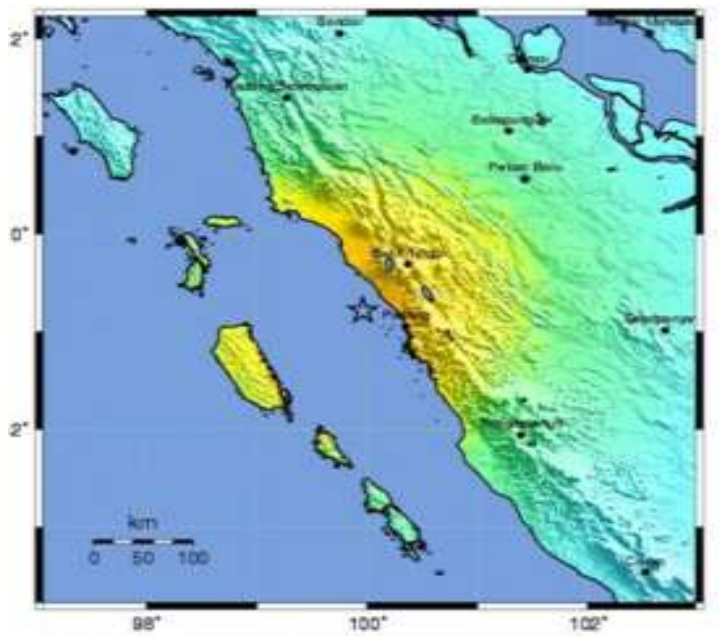

Fig.1 Earthquake location of September 302009 $[10,11]$.

\section{LITERATURE REVIEW}

Naturally, earthquakes cannot be avoided and are very difficult to predict or predict, so that when they happened they caused a lot of losses and casualties [12]. The level of strength of an earthquake is divided into 3 levels based on the damage it causes. Various factors can cause earthquakes. However, most earthquakes are caused by the release of energy generated by the pressure exerted by the moving plates of the earth. Over time the pressure increases and eventually reaches a state where the pressure can no longer be held by the edge of the plate. That's when an earthquake will occur [13].
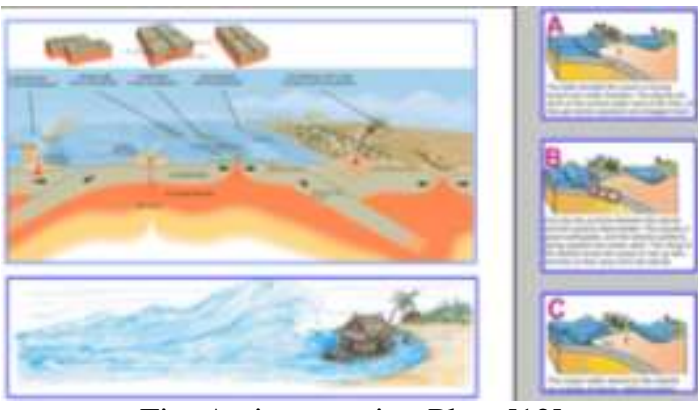

Fig. Action reaction Plate [12] 


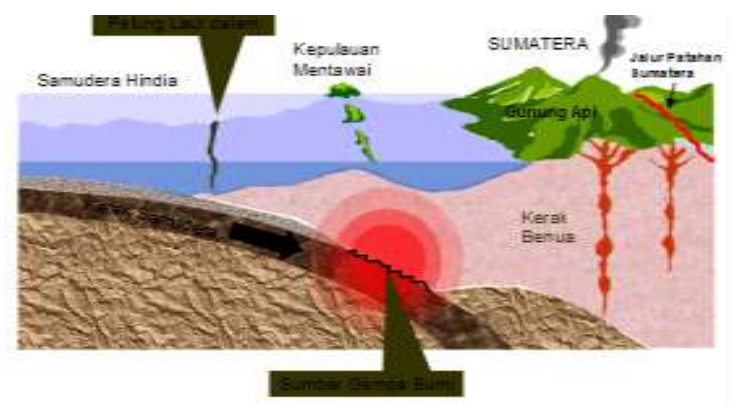

Fig. 3 Island and plate rupture [12]

Various progress has been made in predicting earthquake events, especially in developed

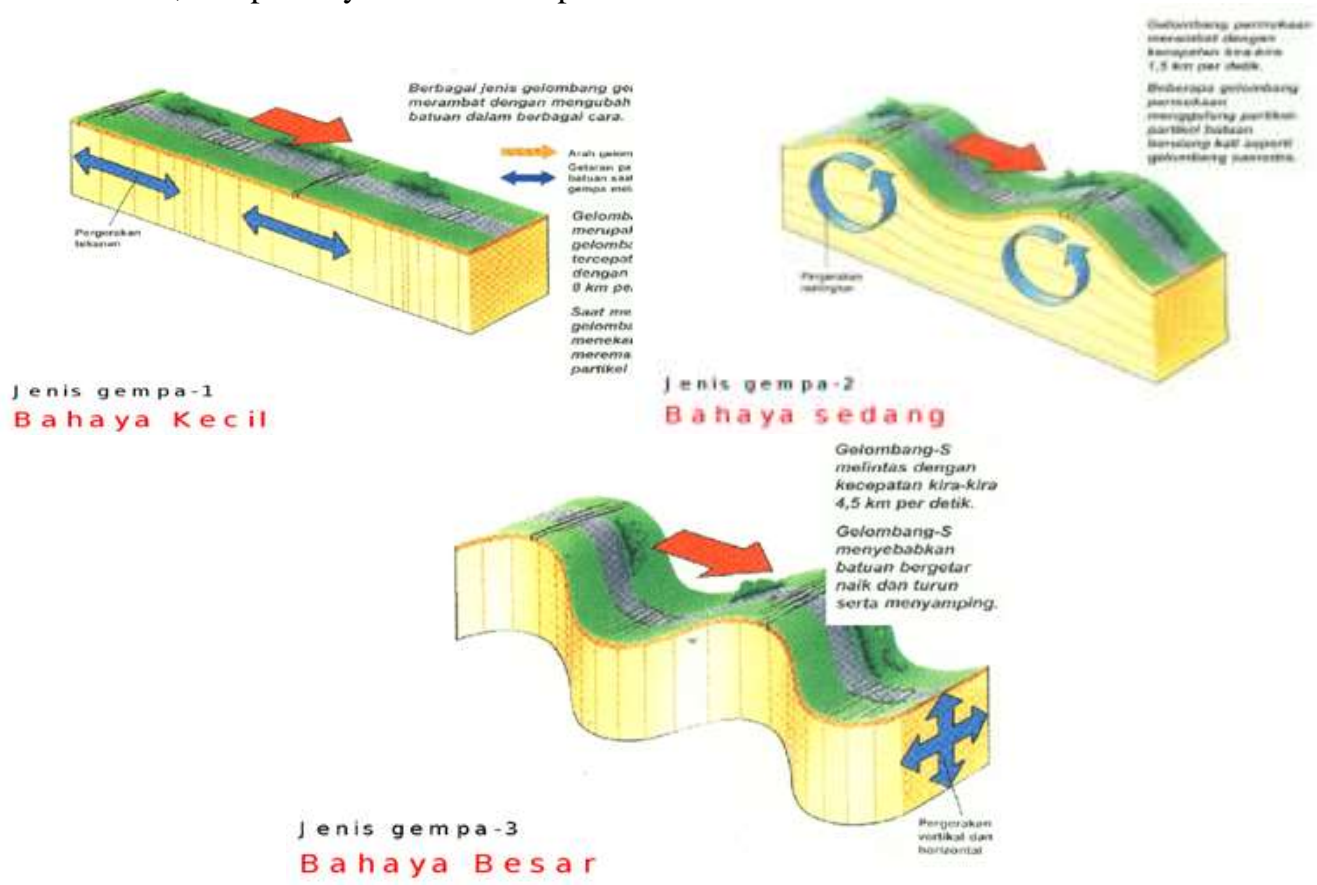

Fig. 4 Types of earthquake waves [14]

Earthquakes cause vibrations of varying magnitude, ranging from very small that are difficult to feel to powerful shocks that can collapse sturdy though. The result is not only loss countries such as the United States and Japan. Even so, it is still difficult to use it as a basis for avoiding the dangers arising from the earthquake that occurred, especially about the economic and psychological impacts. So it would be more appropriate to take actions such as designing earthquake-resistant buildings, dams, bridges, and so on based on the results of research on previous earthquakes [13]. The vibrations generated by the earthquake occur below the earth's surface and spread to the surface in the form of waves. of property and property, but even human and animal lives are threatened [16-18]. The Image of damage at the earthquake stage can be seen in Fig. 5 below.

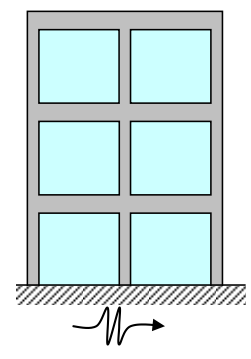

earthquakes

\section{Structural failure due to earthquake}

- Very strong seismic force = liquefaction Columns are not anchored properly to foundation $=$ column cuttings or length of distribution incoming

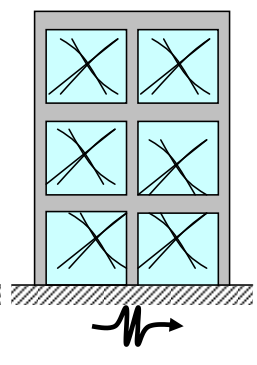

b. Strong earthquake

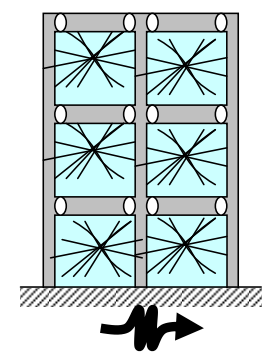

c. The earthquake was very strons

Fig. 5 structural failure due to the earthquake [19] 


\section{Earthquake effect activities}

Naturally, earthquakes cannot be avoided and it is very difficult to predict or predict so that when they occur they cause a lot of loss and casualties. Earthquake resistant structures criteria:

- Due to small and moderate earthquakes (1-5 SR), the building is still strong, including elements structural (columns, beams, floors), as well as non-structural (walls, windows, ceilings, etc.)

- Due to strong earthquakes ( 6-7SR), nonstructural elements have started to crack or collapse, except for the structural elements.

- As a result of a very strong earthquake (> 8 on the Richter scale), some structural and nonstructural elements will collapse, but the collapse is planned in such a way so as not to cause many casualties [20,21).

The earthquake strength level is divided into 12 levels based on the damage it causes [22]. According to [23] the social behavior patterns of children aged 5-16 years include the tendency of children's social behavior to withdraw from social interactions or expand their social interactions, patterns of social behavior tendencies of children who are easy to react to events or are calm, tendencies the child's social behavior becomes passive or dominant. If a child shows his social orientation in one of the patterns above, then his tendency will be followed until adulthood.

The characteristics of social and emotional development in children in grades V to VI of elementary school are easy to be awakened, begin to grow a sense of love like adults, pride develops, wants to know everything, longs for recognition from groups, is proud of the success he has achieved, likes group activities, is loyal to the group. This makes it easier to direct elementary school children to save themselves in the event of a natural disaster.

\section{METHODS}

This activity was carried out at Elementary School 31 Pasir Kandang, Koto Tangah Subdistrict, Padang City, West Sumatra Province, for 1 day with the technical implementation of direct socialization regarding earthquake disaster mitigation efforts in images thematic map (Fig. 6).

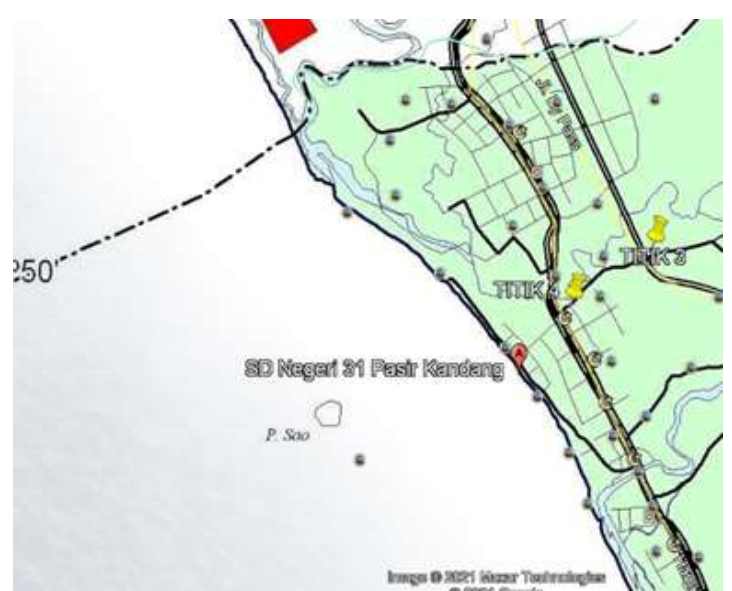

Fig. 6 Tematik Map of research location

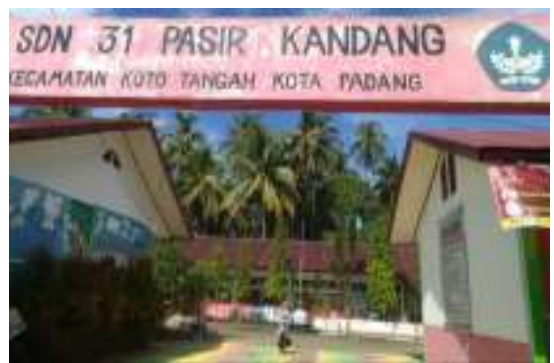

Fig. 7 Elementary School 31 Pasir Kandang

Socialization was carried out by providing explanations related to earthquake disaster mitigation efforts, of course by using language and terms that can be understood by elementary school students. Before and after socialization, students were given a questionnaire to see the level of knowledge of the participants. Data that has been obtained through questionnaires before and after outreach/socialization about natural disasters is processed using Excel to display data in graphical form to make it easier to read the data, also equipped with documentary evidence to strengthen the results of analysis and discussion.

\section{RESULTS}

Respondents to this activity were students of Elementary School 31 Pasir Kandang grades V to VI. The number of students who filled out the questionnaire was 32 people, consisting of 19 boys (59\%) and 13 girls (41\%). The selection of respondents in class VI with an age range of 12-13 years is because they already have a better social orientation than the lower classes, have a very large sense of curiosity, and are easy to react to an incident [24]. Based on the results of filling in the questionnaire conducted, it is known that $13 \%$ of respondents have never experienced natural disasters, the rest have experienced natural disasters as many as $84 \%$ (Fig. 8). 


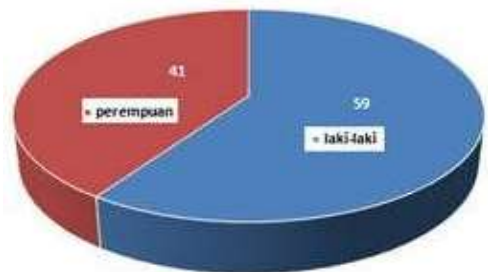

Fig. 8 Percentage of respondents based on gender

Where $100 \%$ of respondents said that there has never been any counseling/socialization about earthquake natural disasters in their schools. Questions are given in the form of a questionnaire, and distributed twice, namely before and after socialization about earthquake natural disasters with the same questionnaire questions. From the results of filling in the questionnaire, it was obtained more satisfactory results after the socialization was carried out. Post-test respondents the average percentage of respondents who answered correctly reached $79.4 \%$. This shows that respondents get additional knowledge about what to do when an earthquake occurs, whether accompanied by a tsunami or not. The questions on the questionnaire are as follows:

1. Natural disasters are disasters caused by...

2. Below that are included in natural disasters are...

3. In your opinion, what causes an earthquake is...

4. Can an earthquake be predicted when it will occur?

5. Will an earthquake with a large strength be followed by an earthquake with a small strength (aftershock)?

6. The actions that should be taken in the event of an earthquake are...

7. What do you need to save in the event of an earthquake?

8. If you are on vacation at the beach and you hear an earthquake warning alarm accompanied by a tsunami what you will do is...

9. If an earthquake occurs while you are in class and you don't have time to go outside, what you will do is...

10. If an earthquake occurs when you are outside the room, what you need to stay away from is, except.

Table 2. Results of filling out the questionnaire before and after socialization

\begin{tabular}{ccccc}
\hline \multirow{2}{*}{ No } & \multicolumn{2}{c}{$\begin{array}{c}\text { Before } \\
\text { Socialization }\end{array}$} & \multicolumn{2}{c}{$\begin{array}{c}\text { After } \\
\text { socialization }\end{array}$} \\
\cline { 2 - 5 } & $\begin{array}{c}\text { True } \\
(\boldsymbol{\%})\end{array}$ & $\begin{array}{c}\text { Wrong } \\
(\boldsymbol{\%})\end{array}$ & $\begin{array}{c}\text { True } \\
(\boldsymbol{\%})\end{array}$ & $\begin{array}{c}\text { False } \\
(\boldsymbol{\%})\end{array}$ \\
\hline 1 & 38 & 62 & 100 & 0 \\
2 & 78 & 22 & 100 & 0 \\
\hline
\end{tabular}

\begin{tabular}{ccccc}
\hline & \multicolumn{2}{c}{$\begin{array}{c}\text { Before } \\
\text { Socialization }\end{array}$} & \multicolumn{2}{c}{$\begin{array}{c}\text { After } \\
\text { socialization }\end{array}$} \\
\cline { 2 - 5 } Tro & True & Wrong & $\begin{array}{c}\text { True } \\
(\boldsymbol{\%})\end{array}$ & $\begin{array}{c}\text { False } \\
(\boldsymbol{\%})\end{array}$ \\
\hline 3 & 50 & 50 & 100 & 0 \\
4 & 78 & 22 & 88 & 12 \\
5 & 69 & 31 & 78 & 22 \\
6 & 31 & 69 & 75 & 25 \\
7 & 16 & 84 & 78 & 22 \\
8 & 25 & 75 & 38 & 62 \\
9 & 34 & 66 & 59 & 41 \\
10 & 25 & 75 & 78 & 22 \\
\hline Average & 44,4 & 55.6 & 79.4 & 20.6 \\
\hline
\end{tabular}

After the post-test, respondents are given leaflets as shown in Fig 9. Leaflets contain information about what to do before an earthquake occurs, during an earthquake, and after an earthquake. While posters were given to the school, affixed to the school wall magazine (wall magazine) as a form of socialization to all students.

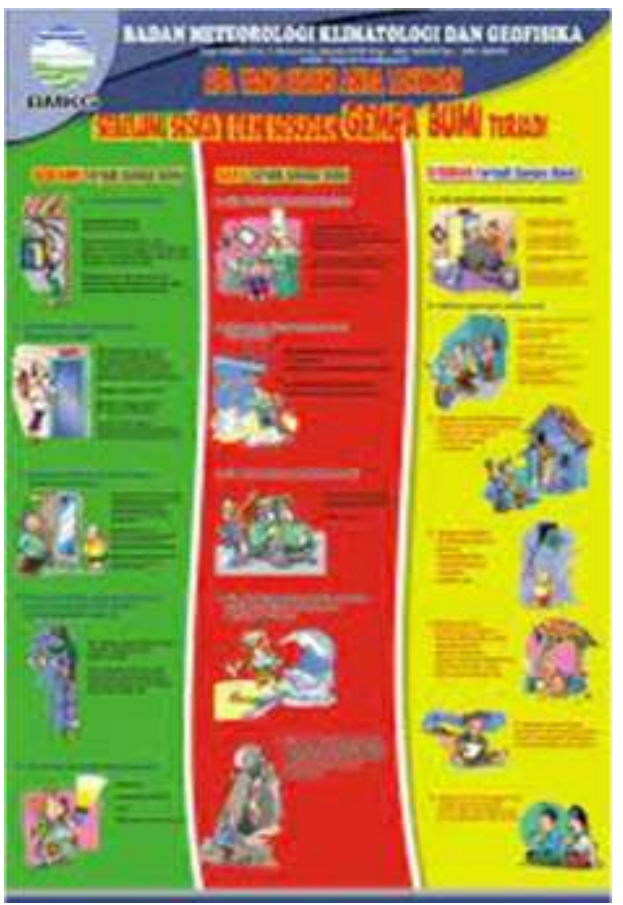

Fig. 9 Earthquake anticipation leaflet

\section{CONCLUSION}

Based on the results of filling out the questionnaire before and after outreach/socialization about natural disasters, especially earthquakes and tsunamis, it can be concluded that with counseling for grade V to VI students at Elementary School 31 Pasir Kandang students already know about the types of natural disasters and how to save themselves when a 
disaster occurs. This can be seen from the average percentage of students who answered correctly during the pre-test was $44.4 \%$ and the post-test results showed the average percentage of students who answered correctly became $79.4 \%$.

\section{ACKNOWLEDGEMENTS}

This writing this literature reviews can be carried out smoothly, because of the help and cooperation of various parties. Therefore, the author would like to thank Prof. Dr. Dedi Hermon, MP as the Deputy Director II of the Postgraduate Universitas Negeri (also chairman of the course of disaster risk management, disaster mitigation, and Geography Information Systems/GIS in the Doctoral Program in Environmental Science, Universitas Negeri Padang) who have provided the opportunity and time to sharpen the academic ability my, especially in the field of disaster environmental.

\section{REFERENCES}

[1] Hermon D. Geografi Bencana Alam. Jakarta: PT RajaGrafindo Persada, 2015

[2] Hermon D. Climate Change Mitigation. Jakarta: PT RajaGrafindo Persada, 2017.

[3] Hermon D. Mitigation and Adaptation: Disaster of Climate Change. India: Sara Book Publication, 2019

[4] Arman A. Studi Kegagalan Struktur Dan Perbaikan Gedung Pusat Jantung Regional (PJR) Rsud M. Jamil Padang Pasca Gempa 30 September 2009. Jurnal Momentum, 2013, 14(1).

[5] Arman A. Kekuatan Balok Beton Bertulang Bambu Dengan Beberapa Perlakuan Pada Tulangan. Jurnal Momentum, 2018, 20(1), 31-37.

[6] Arman A. Kajian Kuat Tekan Beton Normal Menggunakan Standar SNI 7656-2012 Dan ASTM C 136-06. Rang Teknik Journal, 2019, 1(2), 271221.

[7] Lange D., Tilmann F J., Rietbrock A., and Natawidjaja D H. The Relation of the 30 September $2009 \mathrm{Mw} 7.6$ Earthquake to the Structure of the West Sumatran Subduction Zone. In AGU Fall Meeting Abstracts, 2009, Vol. 2009, pp. U13E-2079.

[8] Vigny C. The Earthquake of Padang, Sumatra of 30 September 2009-scientific information and update. update. 2009

[9] Karimi S. Return Migration After 30 September 2009 Earthquake in West Sumatra, Indonesia. Journal of Asian Development, 2017, 3(1), 144-155
[10] Fuady A., Pakasi T A., and Mansyur M. Primary health centre disaster preparedness after the earthquake in Padang Pariaman, West Sumatra, Indonesia. BMC research notes, 2011, 4(1), 1-5

[11] Wardani S P R., and Muntohar A S. Lessons Learned from the Recent Natural Disasters in Indonesia. In Geotechnical Predictions and Practice in Dealing with Geohazards, 2013. pp. 47-59. Springer, Dordrecht

[12] Ghobarah A., Saatcioglu M., and Nistor I. The impact of the 26 December 2004 earthquake and tsunami on structures and infrastructure. Engineering structures, 2006, 28(2), 312-326

[13] Arman A., and Saputra A M. Pengaruh Penambahan Kapur Padang Panjang Pengganti Semen Untuk Beton Normal. Jurnal Momentum, 2015, 17(1)

[14] Honda H. Earthquake mechanism and seismic waves. Journal of Physics of the Earth, 1962, 10(2), 1-97

[15] Sharma S., and Judd W R. Underground opening damage from earthquakes. Engineering geology, 1991, 30(3-4), 263276.

[16] Oktorie O., Rusdi., Heldi., Barlian E., Putra A., and Ramadhan R. Disaster Mitigation Based on Environmental of Coastal Area Communities in Pariaman City Indonesia. Sumatra Journal of Disaster, Geography and Geography Education, 2019, 3(2), 202-207

[17] Triyatno., Febriandi., Putra A., and Kamal E. Identification of Physical Characteristics and the Change of Mangrove Region in Coastal Southern Part of Padang City, West SumatraIndonesia. Sumatra Journal of Disaster, Geography and Geography Education, 2019, 3(1), 87-93

[18] Memito M., Hasmita L., Sekarrini C E., Hermon D., Umar I., and Putra A. Spatial Evacuation Analysis Based on Mount Kaba Volcano, Bengkulu Indonesia Disaster Mitigation Eruption. Science and Environmental Journal for Postgraduate, 2020, 3(1), 54-62

[19] Ismail F A. Studi pengaruh pemasangan angkur dari kolom ke dinding bata pada rumah sederhana akibat beban gempa. Jurnal Rekayasa Sipil (JRS-Unand), 2010, 6(1), 3744

[20] Ismail F A., Siregar N., and Al Jauhari Z. The effect of tsunami loads on Pasar Raya Inpres Block III building in Padang City based on FEMA P-646. MATEC Web of Conferences, 2019, 258, 03020 
[21] Ismail F A., Hakam A., Hape M M., and Asmirza M S. Quick Assessment Procedures For Two Stories Building Based On Numerical Simulation Results. International Journal, 2019, 17(60), 105-109.

[22] Husrin S., Kongko W., and Putera A. Tsunami Vulnerability of Critical Infrastructures in the City of Padang, West

Sumatera. The Proceeding of SIBE. 2013.

[23] Ibrahim R. Pembinaan Perilaku Sosial Melalui Penjas. Jakarta: Ditjen Dikdasmen, Depdiknas, 2001

[24] Supandi. Strategi Belajar Mengajar Pendidikan Jasmani dan Kesehatan. Jakarta : DEPDIKBUD. 1992. 